\title{
A Simple and Selective Nanocatalytic Resonance Rayleigh Scattering Spectral Method for the Determination of Trace Re
}

\author{
Shengmian Wang, Guiqing Wen, Tingsheng Li, Xianjiu Liao, Aihui Liang, and Zhiliang Jiang
}

Key Laboratory of Ecology of Rare and Endangered Species and Environmental Protection of Ministry of Education, Guangxi Normal University, Guilin 541004, China

Correspondence should be addressed to Aihui Liang; ahliang2008@163.com

Received 19 June 2012; Accepted 3 October 2012

Academic Editor: D. Sajan

Copyright (C) 2013 Shengmian Wang et al. This is an open access article distributed under the Creative Commons Attribution License, which permits unrestricted use, distribution, and reproduction in any medium, provided the original work is properly cited.

In the $\mathrm{HCl}$ medium, rhenium (VII) or Re nanoparticles exhibited strong catalytic effect on the slow Te particle reaction between $\mathrm{Te}(\mathrm{VI})$ and $\mathrm{Sn}(\mathrm{II})$ at $70^{\circ} \mathrm{C}$. The product of formed Te particles shows two strong resonance Rayleigh scattering peaks at $778 \mathrm{~nm}$ and $540 \mathrm{~nm}$. The RS intensity at $778 \mathrm{~nm}$ enhanced linearly with Re concentration. The enhanced RS intensity was linear Re concentration in the range of $0.01-2.0 \mathrm{nmol} \cdot \mathrm{L}^{-1}$, with a detection limit of $0.005 \mathrm{nmol} \cdot \mathrm{L}^{-1}$ Re. This method was applied to the analysis of Re in ore sample, and the results were in agreement with that of the spectrophotometry.

\section{Introduction}

Rhenium $(\mathrm{Re})$ is a precious and rare metal element that exists in the lithosphere at a low content. Re is of big rigidity, anticautery, wearable ability, and good ductility that has been utilized in national defense, aviation and spaceflight, and special heating ion materials [1]. Recently, the Re-Os isotope system has been used in geochemistry, formed ore source tracer, and globe evolvement [2]. At the same time, the Re complexes were interesting to people, because they have photoisomerization and anticancer functions [3, 4]. At present, the determination of Re includes spectrophotometry, polarography, neutron activation analysis (NAA), and inductively coupled plasma mass spectrometry (ICP-MS). The spectrophotometry is simple and low cost, but its sensitivity is not high [5-7]. The $\mathrm{Cu}(\mathrm{II})-\mathrm{Te}(\mathrm{IV})$ catalytic polarographic system was used to determine $0.001-0.015 \mu \mathrm{g} / \mathrm{mL}$ Re with high sensitivity [8], but the harmful mercury electrode was used. The NNA has high sensitivity and accuracy, but the equipment was expensive and the nuclear radiation is harmful to the human body [9]. The ICP-MS was reported to detect Re as low as $0.001-0.1 \mathrm{ng} \cdot \mathrm{mL}^{-1}$; its main shortage is expensive equipment [10-12]. Thus, it is necessary to a simple and low-cost, highly sensitive, and selective method for Re. Resonance Rayleigh scattering (or resonance scattering, RS) spectral method is simple, convenient, and sensitive. It has been applied in the analysis of trace inorganic ions such as $\mathrm{Hg}(\mathrm{II}), \mathrm{Cd}(\mathrm{II}), \mathrm{Pb}(\mathrm{II}), \mathrm{Mo}(\mathrm{VI})$, and $\mathrm{Cr}(\mathrm{VI})$ metal ions, and organic compounds [13-18]. Based on the catalytic effect of inorganic metal ions, a catalytic RSS method has been proposed for Se [19]. Nanogold has good catalysis and has been combined with immunoreaction to detect antigens [20, 21]. To date, there is no report on an RS method for the determination of trace Re. In this work, a rapid and highly sensitive and selective nanocatalytic RS method is proposed to detect Re, coupling the nanocatalytic reaction with the RS effect of Te particles.

\section{Experimental}

2.1. Apparatus. A model of Cary Eclipse fluorescence spectrophotometry (Varian Co., USA) was used, with a PMT voltage of $400 \mathrm{~V}$, both excited slit and emission slit of $5 \mathrm{~nm}$, emission filter of $1 \% T$ attenuator, and the excited wavelength $\lambda_{\text {ex }}$ being equal to the emission wavelength $\lambda_{\text {em }}(\Delta \lambda=$ $0)$. A model of Nano-ZS90 nanometer and zeta potential analytical meter (Malvern Co., England), a model of TU1901 spectrophotometry (Beijing Tongyong Instrumental Co., China), and a model of DK- $8 \mathrm{~B}$ thermostatic meter (Shanghai Jinhong Co., China) were used. 

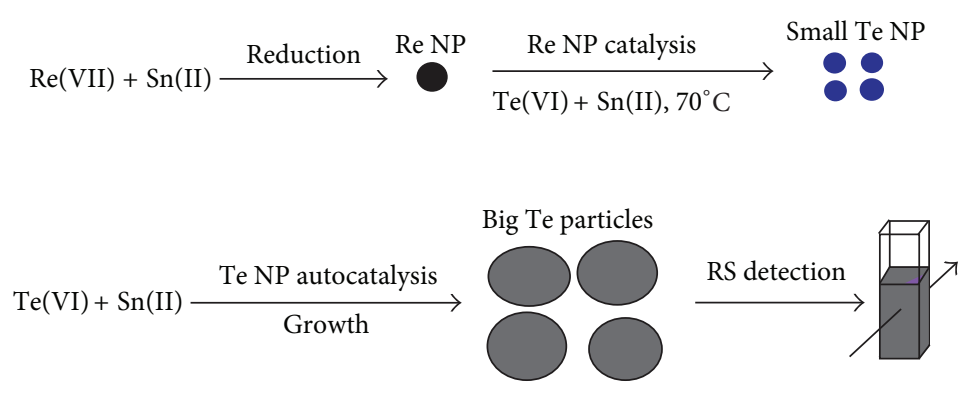

FIGURE 1: Analytical principle of the nanocatalytic RS method for Re.

2.2. Reagents. A $1.0 \times 10^{-3} \mathrm{~mol} \cdot \mathrm{L}^{-1} \mathrm{Re}(\mathrm{VII})$ stock standard solution was prepared using $\mathrm{NH}_{4} \mathrm{ReO}_{4}$. To obtain a $0.90 \mathrm{~mol} \cdot \mathrm{L}^{-1} \mathrm{SnCl}_{2}$ containing $3.6 \mathrm{~mol} \cdot \mathrm{L}^{-1} \mathrm{HCl}$, a $20.3 \mathrm{~g}$ $\mathrm{SnCl}_{2} \cdot 2 \mathrm{H}_{2} \mathrm{O}$ was dissolved in $30 \mathrm{~mL} 12 \mathrm{~mol} \cdot \mathrm{L}^{-1} \mathrm{HCl}$ solution and diluted to $100 \mathrm{~mL}$. A $0.012 \mathrm{~mol} \cdot \mathrm{L}^{-1} \mathrm{Na}_{2} \mathrm{TeO}_{4}$ solution, containing $0.6 \mathrm{~mol} \cdot \mathrm{L}^{-1} \mathrm{HCl}$ was prepared by dissolving $0.33 \mathrm{~g}$ $\mathrm{Na}_{2} \mathrm{TeO}_{4} \cdot 2 \mathrm{H}_{2} \mathrm{O}$ into $5 \mathrm{~mL} \mathrm{HCl}$ and then diluted to $100 \mathrm{~mL}$. The $1.0 \times 10^{-4} \mathrm{~mol} \cdot \mathrm{L}^{-1} \mathrm{Re}$ and $\mathrm{Te}$ nanoparticle colloidal solutions were prepared by $\mathrm{NaBH}_{4}$ reduction procedure. All reagents were of analytical grade, and the water used in experiments was doubly distilled water.

2.3. Procedure. Into a $5 \mathrm{~mL}$ test tube, $0.3 \mathrm{~mL} 0.012 \mathrm{~mol} \cdot \mathrm{L}^{-1}$ $\mathrm{Te}(\mathrm{VI}), 0.20 \mathrm{~mL} 0.3 \mathrm{~mol} \cdot \mathrm{L}^{-1}$ tartaric acid, $0.7 \mathrm{~mL} 0.90 \mathrm{~mol} \cdot \mathrm{L}^{-1}$ $\mathrm{Sn}$ (II), and $0.36 \mathrm{~mL} 1.0 \times 10^{-8} \mathrm{~mol} \cdot \mathrm{L}^{-1} \mathrm{Re}(\mathrm{VII})$ were added. Then the mixture was diluted to $3 \mathrm{~mL}$ with water, mixed well and heated at $70^{\circ} \mathrm{C}$ for $10 \mathrm{~min}$. Finally, the reaction was stoped by cooling with tap water. The RS spectra and the RS intensity at $778 \mathrm{~nm}\left(I_{778 \mathrm{~nm}}\right)$ were recorded by the fluorescence spectrophotometer. The blank without factor B $\left(I_{778 \mathrm{~nm}}\right)_{\mathrm{b}}$ was also measured. The value of $\Delta I=I_{778 \mathrm{~nm}}-$ $\left(I_{778 \mathrm{~nm}}\right)_{\mathrm{b}}$ was calculated.

\section{Results and Discussion}

3.1. Principle. The speed of Te particles reaction between $\mathrm{Te}(\mathrm{VI})$ and $\mathrm{Sn}(\mathrm{II})$ was very slow. When $\mathrm{Re}(\mathrm{VII})$ or $\mathrm{Re}$ nanoparticle existed, the Te particle reaction enhanced greatly. Results showed that the prepared Te nanoparticles also exhibited a catalytic effect on the particle reaction; this indicated that the small Te nanoparticles formed also exhibited catalytic activity on the reaction. Thus, autonanocatalysis exists in the nanocatalytic reaction system [22]. When catalyst $\mathrm{Re}$ (VII) concentration increased, the Re nanocatalyst increased, the formed Te particles increased, and the RS intensity at $778 \mathrm{~nm}$ enhanced linearly because the Te particles exhibited a strong RS effect at $778 \mathrm{~nm}$. On these grounds, a nanocatalytic RS method can be developed for the determination of trace Re, as Figures 1 and 2 showed that there are small Te nanoparticles and big Te particles in the nanocatalytic system, with a mean size of $120 \mathrm{~nm}$.

3.2. Resonance Rayleigh Scattering Spectra (RSS). Under the condition, the speed of Te particle reaction between $\mathrm{Te}(\mathrm{VI})$ $\mathrm{Sn}(\mathrm{II})$ is very slow and its synchronous scattering signal was

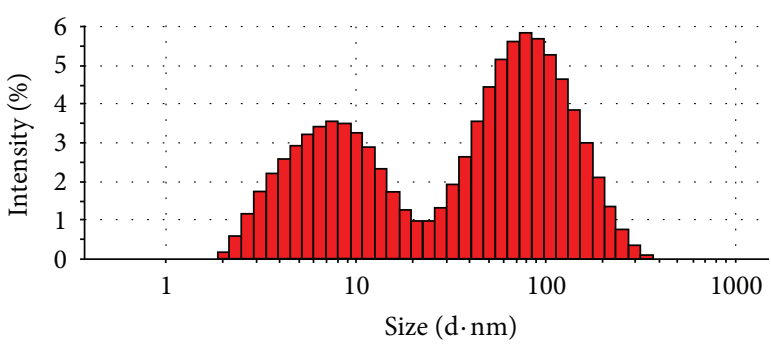

Figure 2: Laser scattering image of the Te particles. $1.2 \mathrm{mmol} \cdot \mathrm{L}^{-1}$ $\mathrm{Na}_{2} \mathrm{TeO}_{4}+0.02 \mathrm{~mol} \cdot \mathrm{L}^{-1}$ tartaric acid $+0.21 \mathrm{~mol} \cdot \mathrm{L}^{-1} \mathrm{SnCl}_{2}+$ $1.2 \mathrm{nmol} \cdot \mathrm{L}^{-1} \mathrm{Re}$.

weak. Upon addition of a catalyst such as $\operatorname{Re}(\mathrm{VII})$ or $\mathrm{Re}$ nanoparticles, the particle reaction enhanced to form more Te particles that exhibited two synchronous scattering peaks at $778 \mathrm{~nm}$ and $540 \mathrm{~nm}$. The RS spectral studies of liquid phase inorganic nanoparticles have showed that three factors such as the light source of the apparatus, absorption of a free molecule in the system, and the RS effect of particles caused synchronous scattering peaks. The light source of the apparatus has the strongest emission at $460 \mathrm{~nm}$, and a scattering peak could appear at $460 \mathrm{~nm}$. The $\mathrm{Sn}(\mathrm{II}), \mathrm{Te}(\mathrm{VI})$, and tartaric acid exhibited a very weak absorption peak at visual wavelength, so the effect of molecular absorption could be ignored. Therefore, the two peaks at $778 \mathrm{~nm}$ and $540 \mathrm{~nm}$ were caused by the RS effect of Te particles and were RS peaks. Figure 3 indicated that the peak at $778 \mathrm{~nm}$ was stronger than the peak at $540 \mathrm{~nm}$; thus a wavelength of $778 \mathrm{~nm}$ was chosen for use.

3.3. Effect of Reagent Concentration. Effect of $\mathrm{Na}_{2} \mathrm{TeO}_{4}$, $\mathrm{SnCl}_{2}, \mathrm{HCl}$, and tartaric acid concentrations were considered respectively. Three acids such as $\mathrm{HCl}, \mathrm{HNO}_{3}$, and $\mathrm{H}_{2} \mathrm{SO}_{4}$ were examined as the reaction medium. Results showed that $\mathrm{HNO}_{3}$ has an oxidative that reacts with $\mathrm{SnCl}_{2}$, and $\mathrm{H}_{2} \mathrm{SO}_{4}$ medium gives low sensitivity. A $0.90 \mathrm{~mol} \cdot \mathrm{L}^{-1} \mathrm{HCl}$, giving high sensitivity, was selected for the reaction that was added in the $\mathrm{SnCl}_{2}$ solution to prevent its hydrolysis. Tartaric acid, containing carboxyl and hydroxy, is a good complex reagent, and it is not only a good activator for the precursor Re(VII) of the nanocatalyst but also a mask agent for eliminating 


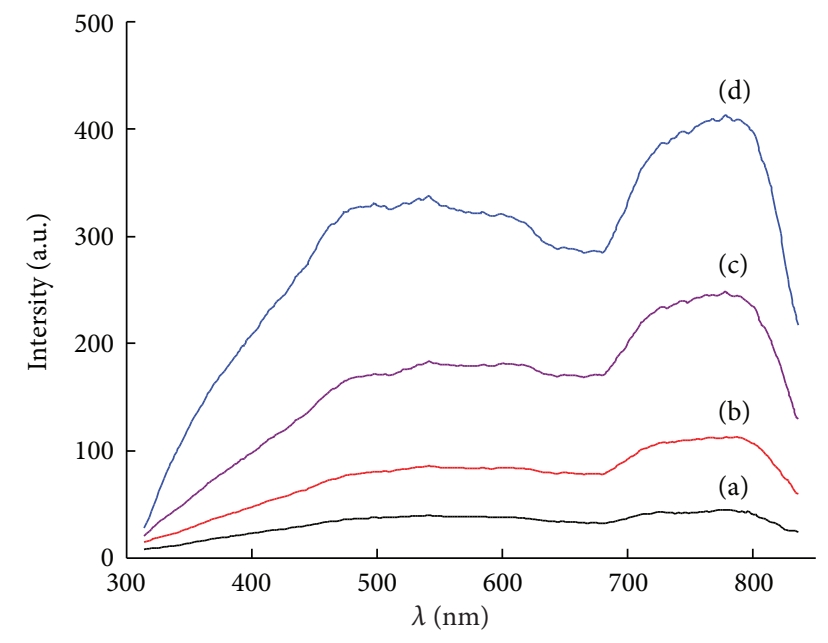

FIGURE 3: RRS of the catalytic system (a): $1.2 \mathrm{mmol} \cdot \mathrm{L}^{-1} \mathrm{Na}_{2} \mathrm{TeO}_{4}+$ $0.02 \mathrm{~mol} \cdot \mathrm{L}^{-1}$ tartaric acid $+0.21 \mathrm{~mol} \cdot \mathrm{L}^{-1} \quad \mathrm{SnCl}_{2} ;$ (b): (a) + $0.40 \mathrm{nmol} \cdot \mathrm{L}^{-1} \mathrm{Re} ;(\mathrm{c}):(\mathrm{a})+1.0 \mathrm{nmol} \cdot \mathrm{L}^{-1} \mathrm{Re},(\mathrm{d}):(\mathrm{a})+2.0 \mathrm{nmol} \cdot \mathrm{L}^{-1}$ Re.

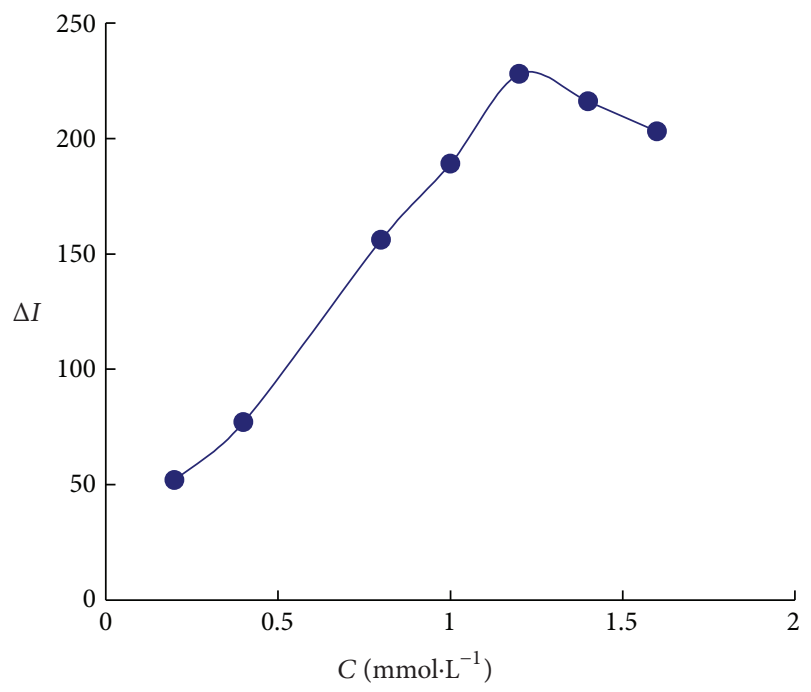

Figure 4: Effect of $\mathrm{Na}_{2} \mathrm{TeO}_{4}$ concentration. $\mathrm{Na}_{2} \mathrm{TeO}_{4}+0.02 \mathrm{~mol} \cdot \mathrm{L}^{-1}$ tartaric acid $+0.21 \mathrm{~mol} \cdot \mathrm{L}^{-1} \mathrm{SnCl}_{2}+1.2 \mathrm{nmol} \cdot \mathrm{L}^{-1} \mathrm{Re}$.

some metal ions. A $0.02 \mathrm{~mol} \cdot \mathrm{L}^{-1}$ tartaric acid, giving good results, was chosen for use. According to the rate equation, the velocity $V=d C_{\mathrm{Te}} / d t$, and the $I_{778 \mathrm{~nm}}=k C_{\mathrm{Te}}$. Thus, the $I_{778 \mathrm{~nm}}$ is proportional to the $V$, that is, the bigger $I_{778 \mathrm{~nm}}$, the bigger $V$. Figure 4 showed that the reaction rate increased with the $\mathrm{Na}_{2} \mathrm{TeO}_{4}$ concentration increasing that indicated the reaction order of $\mathrm{Te}(\mathrm{VI})$ is first. When the $\mathrm{Na}_{2} \mathrm{TeO}_{4}$ concentration was $1.2 \mathrm{mmol} \cdot \mathrm{L}^{-1}$, the formed Te particles are the biggest, and the $\Delta I$ value attained the maximum. Thus, a concentration of $1.2 \mathrm{mmol} \cdot \mathrm{L}^{-1} \mathrm{Na}_{2} \mathrm{TeO}_{4}$ was chosen for use. $\mathrm{Sn}$ (II) is a reducer in the particle reaction, the effect of $\mathrm{Sn}(\mathrm{II})$ concentration on $\Delta I$ was investigated. Figure 5 showed that when the $\operatorname{Sn}(\mathrm{II})$ concentration was less than $0.21 \mathrm{~mol} \cdot \mathrm{L}^{-1}$, when the $\mathrm{Sn}(\mathrm{II})$ concentration increased the formed Te particles increased, and the $\Delta I$ value increased

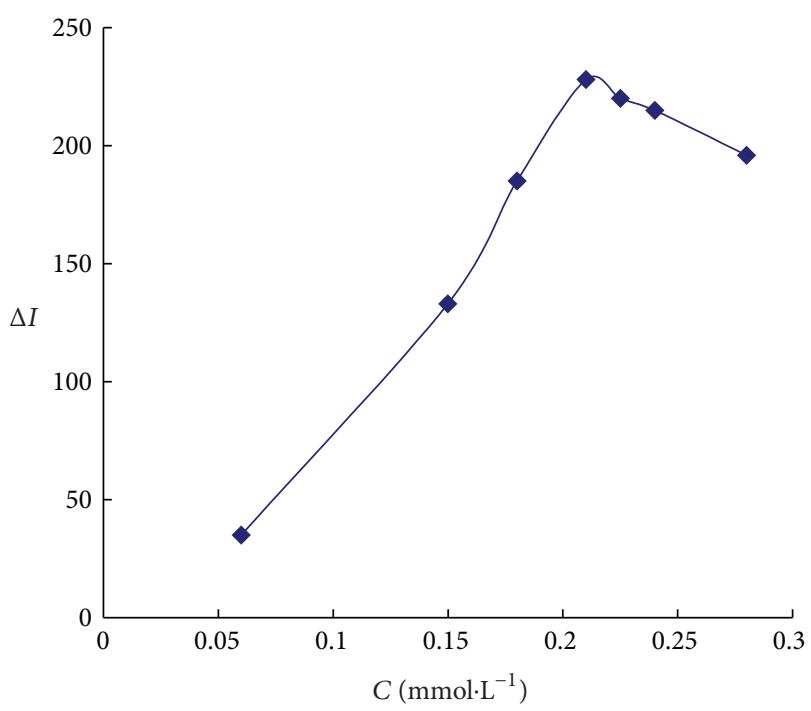

FIgURE 5: Effect of $\mathrm{SnCl}_{2}$ concentration. $1.2 \mathrm{mmol} \mathrm{L}{ }^{-1} \mathrm{Na}_{2} \mathrm{TeO}_{4}+$ $0.02 \mathrm{~mol} \cdot \mathrm{L}^{-1}$ tartaric acid $+\mathrm{SnCl}_{2}+1.2 \mathrm{nmol} \cdot \mathrm{L}^{-1} \mathrm{Re}$.

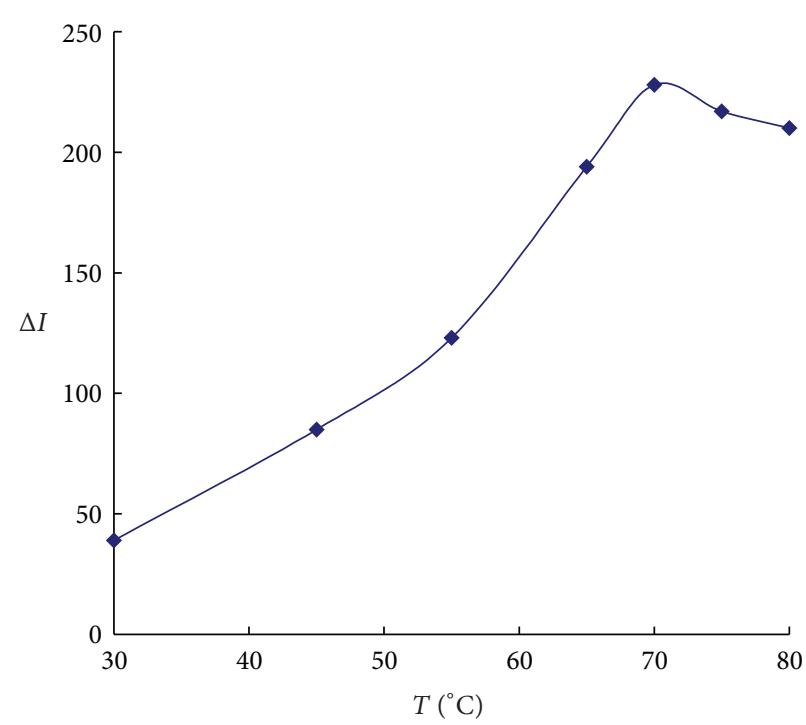

FIgURE 6: Effect of reaction temperature. $1.2 \mathrm{mmol} \cdot \mathrm{L}^{-1} \mathrm{Na}_{2} \mathrm{TeO}_{4}+$ $0.02 \mathrm{~mol} \cdot \mathrm{L}^{-1}$ tartaric acid $+0.21 \mathrm{~mol} \cdot \mathrm{L}^{-1} \mathrm{SnCl}_{2}+1.2 \mathrm{nmol} \cdot \mathrm{L}^{-1} \mathrm{Re}$.

that indicated the reaction order of $\mathrm{Sn}(\mathrm{II})$ is first. When the concentration was higher than $0.24 \mathrm{~mol} \cdot \mathrm{L}^{-1}$, the $\Delta I$ value decreased and the blank value increased. To obtain high sensitivity and low blank, a $0.21 \mathrm{~mol} \cdot \mathrm{L}^{-1} \mathrm{SnCl}_{2}$ was chosen for use.

3.4. Effect of Reaction Temperature and Reaction Time. The influence of reaction temperature $\left(30-80^{\circ} \mathrm{C}\right)$ and reaction time on $\Delta I$ were investigated, respectively. Figure 6 showed that when the temperature was less than $70^{\circ} \mathrm{C}$, the $\Delta I$ value increased with the increase of temperature, and the blank value was low. When the temperature was higher than $75^{\circ} \mathrm{C}$, the $\Delta I$ value decreased and the blank value was high. To obtain high sensitivity, a reaction temperature of $70^{\circ} \mathrm{C}$ was 
TABle 1: Analytical results.

\begin{tabular}{lcccc}
\hline Sample & Found $\left(\mu \mathrm{g} \cdot \mathrm{g}^{-1}\right)$ & Average $\left(\mu \mathrm{g} \cdot \mathrm{g}^{-1}\right)$ & RSD $(\%)$ & ${\text { Spectrophotometry }\left(\mu \mathrm{g} \cdot \mathrm{g}^{-1}\right)}$ \\
\hline 1 & $215.3,211.4,217.4,213.5,214.8$ & $214.5 \pm 2.2$ & 1.0 & 210.6 \\
2 & $315.0,320.8,314.0,316.9,322.0$ & $317.7 \pm 3.4$ & 1.1 & 326.0 \\
3 & $346.2,341.0,357.0,356.2,342.6$ & $348.6 \pm 14.3$ & 4.1 & 346.6 \\
\hline
\end{tabular}

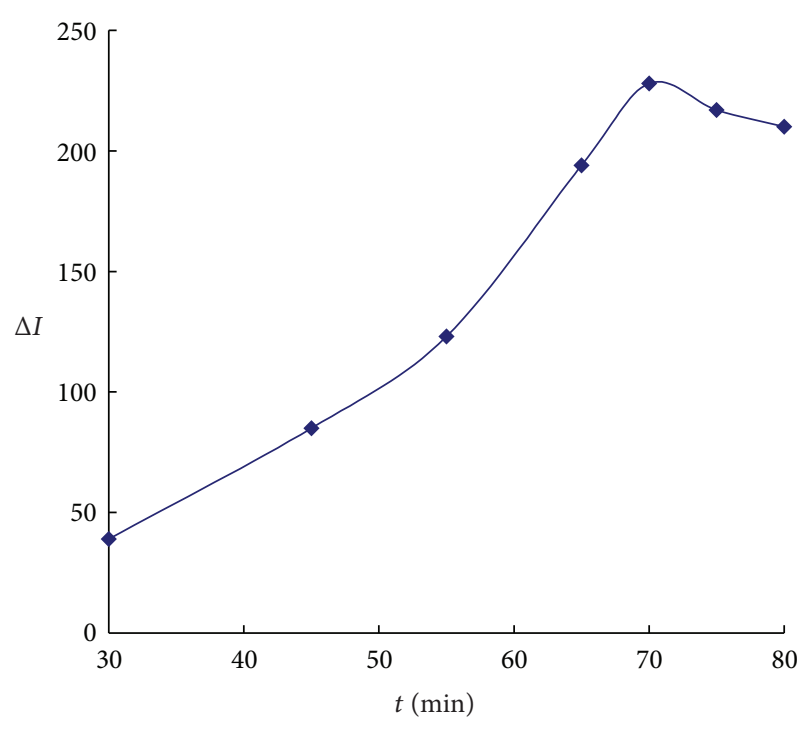

Figure 7: Effect of reaction time. $1.2 \mathrm{mmol} \cdot \mathrm{L}^{-1} \quad \mathrm{Na}_{2} \mathrm{TeO}_{4}+$ $0.02 \mathrm{~mol} \cdot \mathrm{L}^{-1}$ tartaric acid $+0.21 \mathrm{~mol} \cdot \mathrm{L}^{-1} \mathrm{SnCl}_{2}+1.2 \mathrm{nmol} \cdot \mathrm{L}^{-1} \mathrm{Re}$.

chosen for use. Figure 7 indicated that the $\Delta I$ value reached its maximum when the reaction time was $10 \mathrm{~min}$. Thus, a reaction time of $10 \mathrm{~min}$ at a temperature of $70^{\circ} \mathrm{C}$ was selected for use.

3.5. Working Curve. Under the optimal conditions, the RS intensity for different $\mathrm{Re}(\mathrm{VII})$ concentrations was recorded and the working curve was drawn according to the relationship between $\operatorname{Re}(\mathrm{VII})$ concentration $(C)$ and their corresponding $\Delta I$ value. The linear range, linear regression equation, correlation coefficient, and detection limit are $0.01-2.0 \mathrm{nmol} \cdot \mathrm{L}^{-1}, \Delta I=180.6 \mathrm{C}+8.4,0.9965$, and $0.005 \mathrm{nmol} \cdot \mathrm{L}^{-1} \operatorname{Re}(\mathrm{VII})$, respectively. The linear relationship showed that the reaction order of $\operatorname{Re}(\mathrm{VII})$ catalyst is first. Thus, the rate equation can be rewritten as $V=K C_{\mathrm{Re}} C_{\mathrm{Te}} C_{\mathrm{Sn}}$. Comparing with the reported assay [4-12], this nanocatalytic RS method is very highly sensitive, simple, and low cost.

3.6. Effect of Coexistent Substance. According to the procedure, we tested the effect of coexistent substance on the determination of $1.0 \mathrm{nmol} \cdot \mathrm{L}^{-1} \mathrm{Re}(\mathrm{VII})$, with a relative error of $\pm 5 \%$. The results showed that the coexistent substances of 1000 times of $\mathrm{Na}^{+}, \mathrm{K}^{+}, \mathrm{PO}_{4}{ }^{3-}, \mathrm{Al}^{3+}, \mathrm{SiO}_{3}{ }^{2-}$, and $\mathrm{MoO}_{4}{ }^{2-}$, 500 times of $\mathrm{Fe}^{3+}, \mathrm{Ca}^{2+}, \mathrm{Mg}^{2+}, \mathrm{Zn}^{2+}, \mathrm{Pb}^{2+}, \mathrm{Ba}^{2+}$, and $\mathrm{Cu}^{2+}$, 200 times of Se(VI), $\mathrm{Sr}^{2+}, \mathrm{Cd}^{2+}$, and as (III), and 100 times of $\mathrm{Pt}^{4+}, \mathrm{Ni}^{2+}, \mathrm{Ti}(\mathrm{IV})$, and $\mathrm{Cr}^{3+}$ do not interfere with the Re(VII) determination, and the method has good selectivity.
3.7. Analysis of Samples. Three molybdenum ore samples were pretreated, respectively, according to [23] to prepare the sample solution that was determined by this nanocatalytic RS method. The results were listed in Table 1 and are in agreement with those of the spectrophotometry [23]. This indicated that both method results have been good relatively.

\section{Conclusion}

The nanocatalytic reaction of $\mathrm{Te}(\mathrm{VI})$-Sn(II)-Re nanoparticle was studied by resonance Rayleigh scattering spectral technique, and the analytical conditions were optimized. Thus, a simple, rapid, sensitive, and selective nanocatalytic RS method was proposed for the determination of $\mathrm{Re}$ in real samples with good results. These RS method results were agreement with those of the spectrophotometry.

\section{Acknowledgments}

The project is supported by the National Natural Science Foundation of China (nos. 21165005 and 21075023) and the Key Laboratory of Ecology of Rare and Endangered Species and Environmental Protection (Guangxi Normal University, Ministry of Education, China (1101Z005)).

\section{References}

[1] D. G. Pearson and S. J. Woodland, "Solvent extraction/anion exchange separation and determination of PGEs (Os, Ir, Pt, $\mathrm{Pd}, \mathrm{Ru}$ ) and $\mathrm{Re}-\mathrm{Os}$ isotopes in geological samples by isotope dilution ICP-MS," Chemical Geology, vol. 165, no. 1-2, pp. 87-107, 2000.

[2] S. B. Shirey and R. J. Walker, "The Re-Os isotope system in cosmochemistry and high-temperature geochemistry," Annual Review of Earth and Planetary Sciences, vol. 26, pp. 423-500, 1998.

[3] K. P. M. Frin, M. K. Itokazu, and N. Y. M. Iha, " ${ }^{1} H$ NMR spectroscopy as a tool to determine accurate photoisomerization quantum yields of stilbene-like ligands coordinated to rhenium(I) polypyridyl complexes," Inorganica Chimica Acta, vol. 363, no. 2, pp. 294-300, 2010.

[4] S. Wirth, A. U. Wallek, A. Zernickel et al., "Tautomerization of 2-nitroso- $\mathrm{N}$-arylanilines by coordination as $\mathrm{N}, \mathrm{N}^{\prime}$-chelate ligands to rhenium(i) complexes and the anticancer activity of newly synthesized oximine rhenium(i) complexes against human melanoma and leukemia cells in vitro," Journal of Inorganic Biochemistry, vol. 104, no. 7, pp. 774-789, 2010.

[5] O. Bozhkov and L. V. Borisova, "Highly selective catalytic spectrophotometric determination of nanogram amounts of rhenium with $N, N$-dimethyldithiooxamide in alkaline medium," Analytical Communications, vol. 33, no. 4, pp. 133-135, 1996. 
[6] A. Ghosh, K. S. Patel, and R. K. Mishra, "Amidines as extractants: spectrophotometric determination of rhenium in ores as its ternary thiocyanato complex," Analyst, vol. 115, no. 7, pp. 969-971, 1990 .

[7] S. Jin, J. Lv, and L. Xie, "Spectrophotometric determination of rhenium in PtRe catalysts," Analytical Laboratory, vol. 18, pp. 42-45, 1999.

[8] B. C. Xu, "Re Polarographic catalytic hydrogen wave and its application," Chinese Journal of Analytical Chemistry, vol. 14, pp. 340-344, 1986.

[9] C. Zhou, Q. Wang, H. Jiang, Z. Lü, L. Li, and Q. Xu, "Determination of rhenium in copper ores by preconcentration of polyurethane foam-neutron activation analysis," Chinese Journal of Analytical Chemistry, vol. 33, no. 5, pp. 657-660, 2005.

[10] J. Li, X. R. Liang, Y. H. Dong, X. L. Tu, and J. F. Xu, "Measurements of Re-Os isotopic composition in mafic-ultramafic rocks by multi-collector inductively coupled plasma mass spectrometer," Geochimica, vol. 36, pp. 153-160, 2007.

[11] K. Shinotsuka and K. Suzuki, "Simultaneous determination of platinum group elements and rhenium in rock samples using isotope dilution inductively coupled plasma mass spectrometry after cation exchange separation followed by solvent extraction," Analytica Chimica Acta, vol. 603, no. 2, pp. 129-139, 2007.

[12] C. A. Miller, B. Peucker-Ehrenbrink, and L. Ball, "Precise determination of rhenium isotope composition by multi-collector inductively-coupled plasma mass spectrometry," Journal of Analytical Atomic Spectrometry, vol. 24, no. 8, pp. 1069-1078, 2009.

[13] Z. D. Liu, Y. F. Li, J. Ling, and C. Z. Huang, "A localized surface plasmon resonance light-scattering assay of mercury (II) on the basis of $\mathrm{Hg}^{2+}$-DNA complex induced aggregation of gold nanoparticles," Environmental Science and Technology, vol. 43, no. 13, pp. 5022-5027, 2009.

[14] Z. Jiang, J. Li, G. Wen, Q. Liu, and A. Liang, "Nanocatalytic resonance scattering spectral analysis," Science China Chemistry, vol. 53, no. 5, pp. 1049-1054, 2010.

[15] W. Cai, A. H. Liang, Q. Y. Liu, X. J. Liao, Z. L. Jiang, and G. Y. Shang, "Catalytic effect of ReAu nanoalloy on the Te particle reaction and its application to resonance Rayleigh scattering spectral assay of CA125," Luminescence, vol. 26, pp. 305-312, 2011.

[16] J. F. Liu, T. Wen, N. B. Li, and H. Q. Luo, "A sensitive assay of erythrosine using enhanced resonance Rayleigh scattering signals with $\mathrm{Fe}(\text { phen })_{3}{ }^{2+}$ in aqueous ethanol media," Sensors and Actuators B, vol. 160, pp. 1128-1135, 2011.

[17] Y. F. Long, C. Z. Huang, and Y. F. Li, "Hybridization detection of DNA by measuring organic small molecule amplified resonance light scattering signals," Journal of Physical Chemistry B, vol. 111, no. 17, pp. 4535-4538, 2007.

[18] Z. Han, L. Qi, G. Shen, W. Liu, and Y. Chen, "Determination of chromium(VI) by surface plasmon field-enhanced resonance light scattering," Analytical Chemistry, vol. 79, no. 15, pp. 5862-5868, 2007.

[19] Z. Jiang, Q. Liu, and S. Liu, "Catalytic resonance scattering spectral method for the determination of trace amounts of Se," Talanta, vol. 58, no. 4, pp. 635-640, 2002.

[20] Q. Liu, G. Wen, A. Liang, T. Li, and Z. Jiang, "A highly sensitive resonance scattering spectral assay for carcinoembryonic antigen using immunonanogold as probe and nanocatalyst of $\mathrm{NH}_{2} \mathrm{OH}-\mathrm{Cu}(\mathrm{II})$ particle reaction," Bioprocess and Biosystems Engineering, vol. 34, no. 4, pp. 499-504, 2011.
[21] Z. L. Jiang, S. M. Wang, A. H. Liang, and F. X. Zhong, "A highly sensitive resonance scattering spectral assay for $\operatorname{IgG}$ using Fehling reagent-glucose-immunonanogold reaction," Talanta, vol. 77, no. 3, pp. 1191-1196, 2009.

[22] Z. Y. Li, C. H. Han, and J. Y. Shen, "Reaction kinetics of reduction of $\mathrm{Co}^{2+}$ by hydrazine in solution for the preparation of cobalt nanoparticles," Acta Chimica Sinica, vol. 64, no. 4, pp. 295-300, 2006.

[23] B. L. Sun, B. Li, K. Zhou, L. Zhang, and P. P. Yang, "Determination of rhenium in molybdenum ores and flue dust," Rare Metal Materials and Engineering, vol. 40, pp. 2065-2068, 2011. 

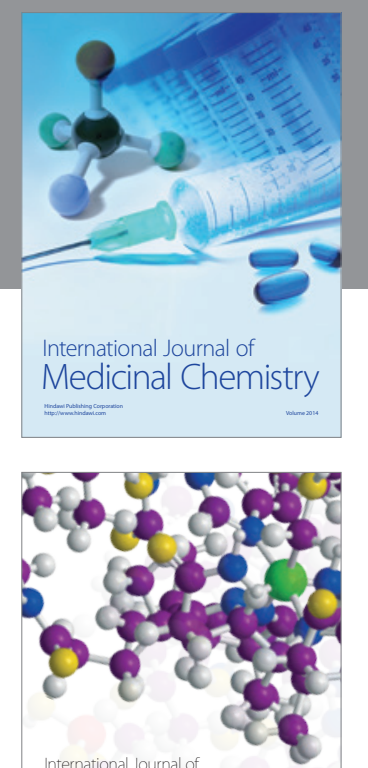

\section{Carbohydrate} Chemistry

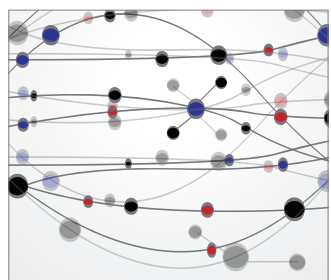

The Scientific World Journal
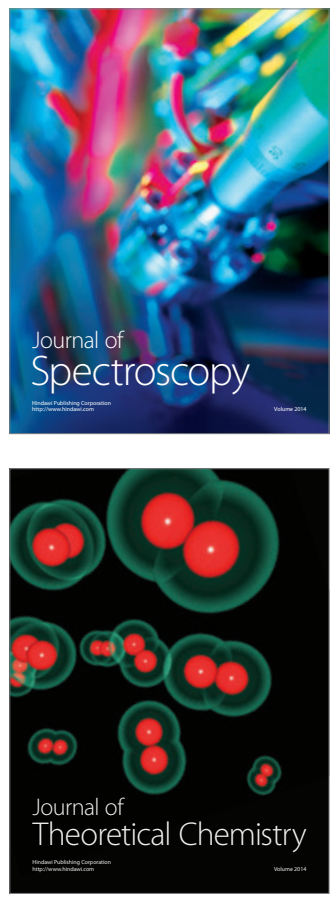
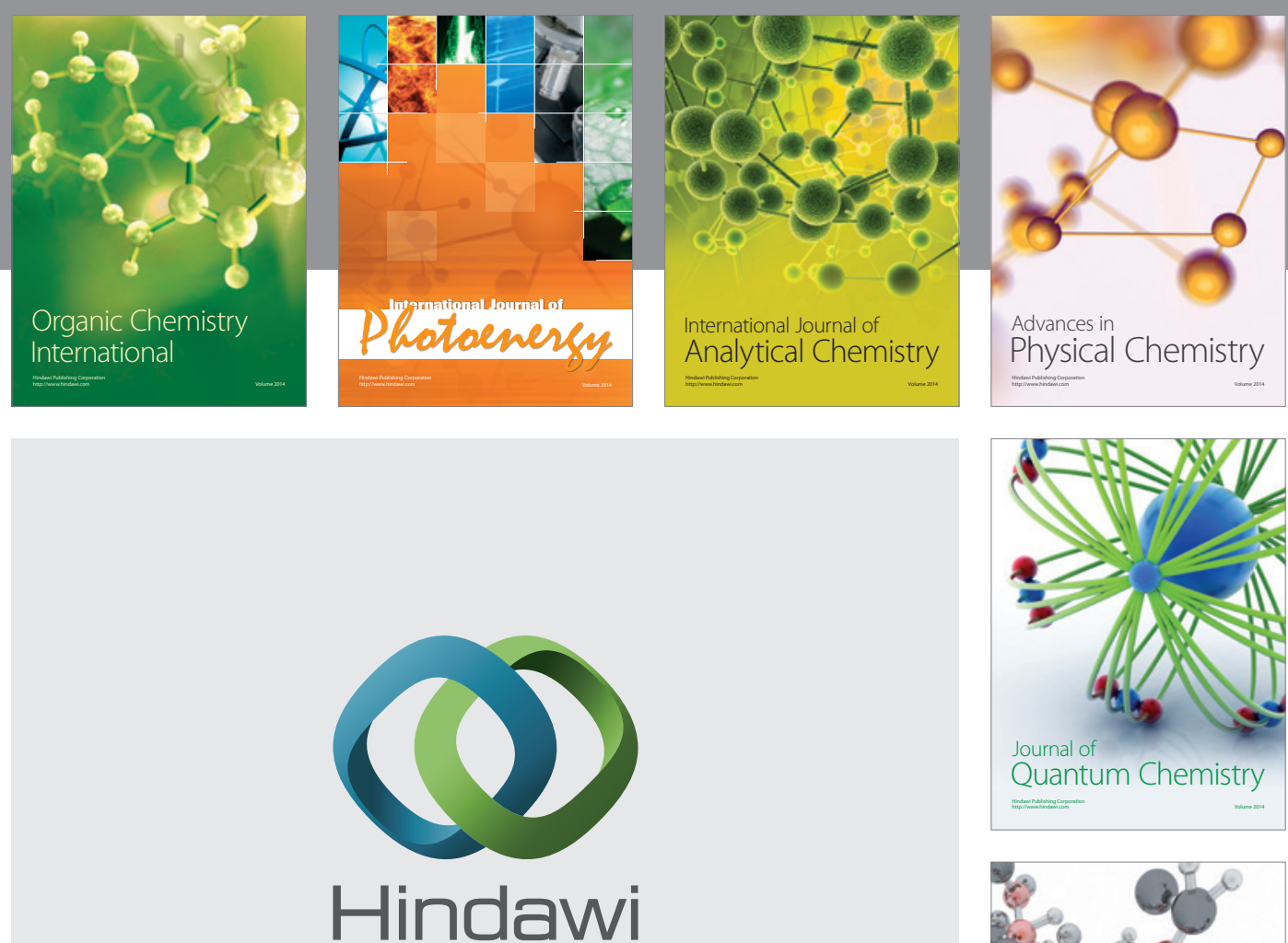

Submit your manuscripts at

http://www.hindawi.com

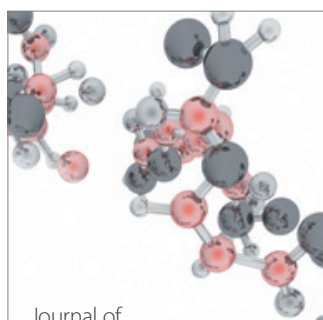

Analytical Methods

in Chemistry

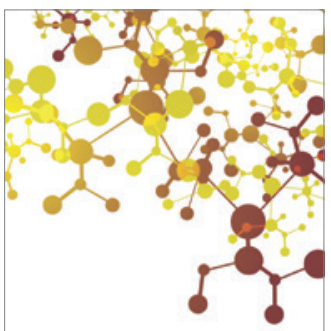

Journal of

Applied Chemistry

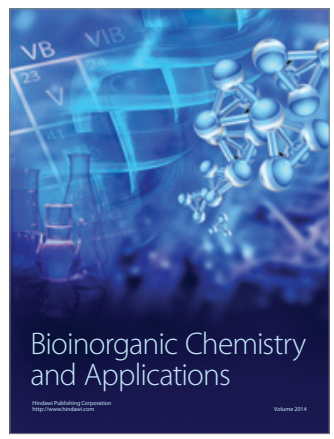

Inorganic Chemistry
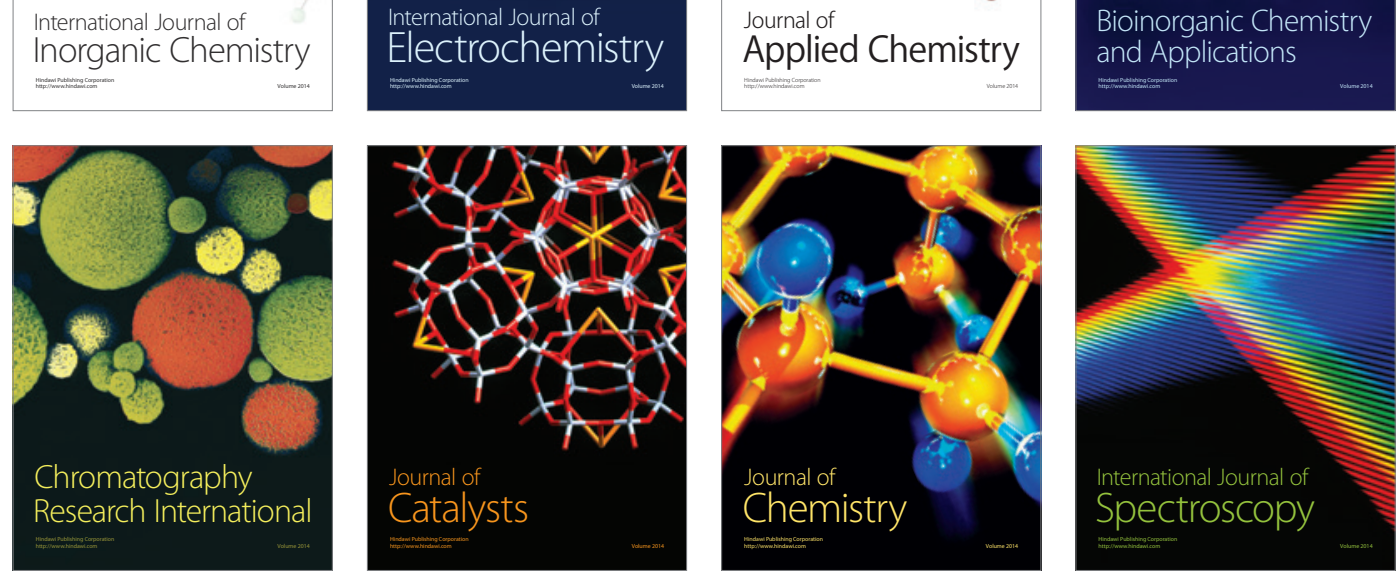